\title{
ACHIEVE THE GOALS OF INCLUSIVE EDUCATION
}

\section{Dr. D. SUMATHI DESINGURAJ}

Assistant Professor, School of Education, Tamil Nadu Open University, Saidapet, Chennai Tamil Nadu India

\begin{abstract}
Inclusive Education deals with the educational wants of each learners, adolescence and adults with a selected target persons that are susceptible to social process. It targets at all stakeholders in the system to be comfortable with varied special needs and see it as a challenge rather than a problem. This paper focuses the aims and the ways to achieve the goals with the help of teachers and educational institutions and identifying the desirable behavior among the students. And this paper points out the concepts and action plan for common classroom for children with special needs, psychological analysis with confidence level of learners interest areas.
\end{abstract}

KEYWORDS: Education, Learners \& Psychological Analysis

Received: Feb 26, 2018; Accepted: Mar 15, 2018; Published: Apr 04, 2018; Paper Id.: IJEEFUSAPR20185

\section{INTRODUCTION}

"Inclusive Education, as an approach which deals with educational needs of every category of learners, youth and adults with a selected target those that are susceptible to social process. It implies each learning community, adolescents - with or while not disabilities having the ability to be told along through access to ordinary pre-school provisions, faculties and community instructional setting with an suitable system of support services. This is possible only in a flexible education system and it targets at all type of educationalists to be comfortable with with varied special needs and see it as a challenge rather than a problem.

\section{CONCEPT OF INCLUSIVE EDUCATION}

This is an incorporated strategy to cater to the needs of special students in a common education environment. Zalizan Jelas (2000) described the term inclusive education as an integration issue whereby participation of pupil with diverse needs is provided for in the face-to-face education system. Inclusive education so provides every learner the chance to be told along while not discrimination. This means that faculties wherever comprehensive education is going down should be sensitive to the variations within the wants of varied learners with disabilities. Inclusive education conjointly offers each educational and community benefits. Various specialists sustain that comprehensive education is that the simplest suggests that for building commonness among learners with special wants and their peers.

\section{Aims \& Objectives}

- The vital aim of education of diverse needs of students is to prepare them live independent life in anywhere.

- Its main objective is to develop helping tendencies and humanity among teachers, peer groups and parents who are interact with diverse needs of students. 
- To provide equal status in education and common life.

- To shape up the vocational skills by participating in arts and crafts work, field trip, survey, technical development skills, sports and various extra academic activites.

- Given opportunity to complete their education.

- $\quad$ Assure that pupil with diverse needs will receive needed requirements for learning.

ROLE OF TEACHER

Psychological Analysis \& Problem solution

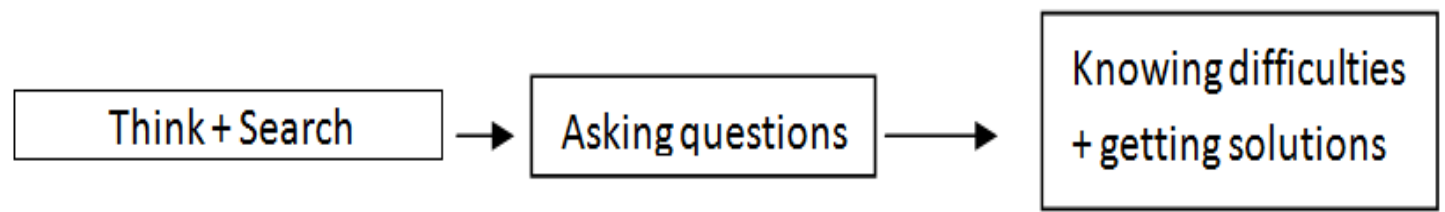

For psychological analysis teacher has to explore the problem area of the children. Then teacher should enquire with children and his/her family members related with problems what teacher finds out in friendly way, and then only can be assured about getting some difficulties in learning. After that the tutor facilitates the learning with level of students.

\section{Special Guidance Beyond School Hour}

Teacher may extent one hour extra time for the needed pupil for their improvement. This strategy may be making a good student teacher relationship.

\section{Fixing the Goal \& Prescribing a List}

Teacher should fix the goal and made encourage achieving the goal by their level with enthusiasm. The student ought to be influenced to construct a list for the learning purpose. Few children may be without any goal. The tutor ought to examine those youngsters \& motivate them to mend the aim for the living him to make a list for each day work.

\section{Celebration in Small Success}

The greatest issue for the success of the lifetime of the student is his encouragement. Teacher should try to celebrate those times with encouraging words.

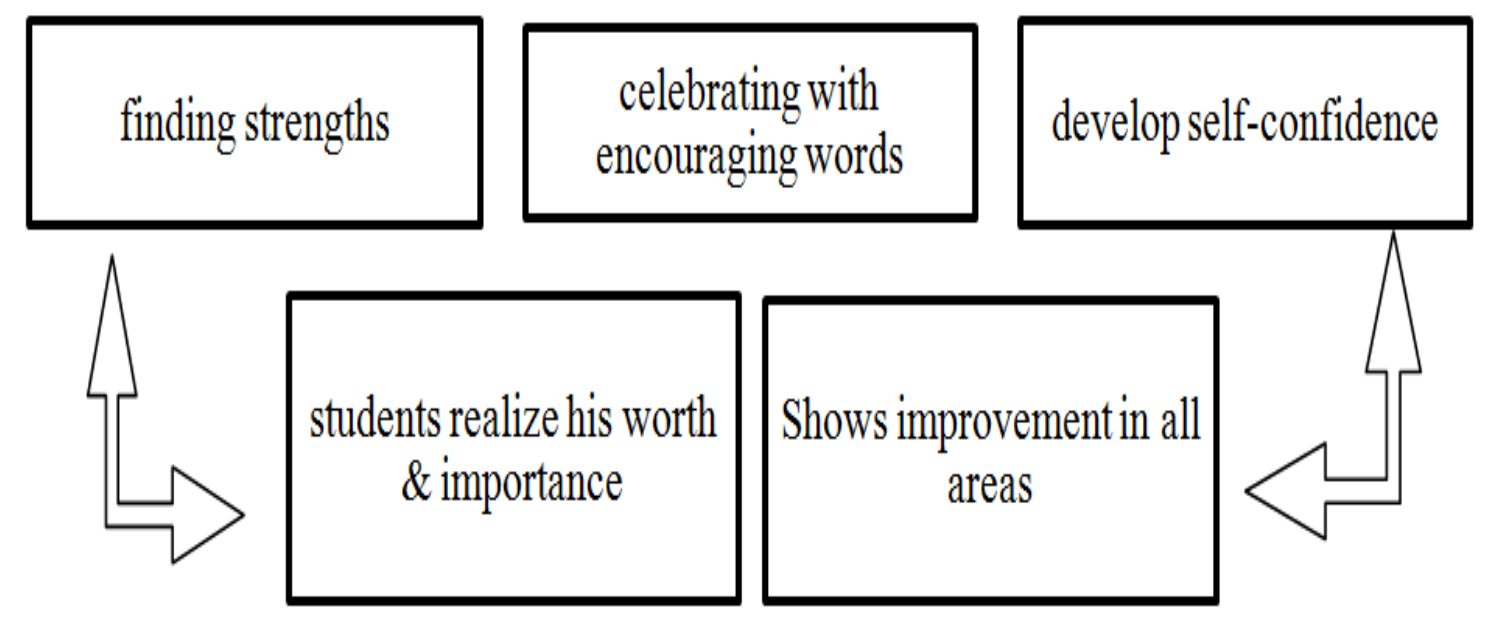




\section{Self Reading Method}

Teacher should motivated for self reacding according to the student's level, interest, eye sight, attitude and aptitude.

\section{Seating Arrangement}

Teacher should arrange the seat for differently abled students in the classroom is convenient. It should be easy access to mingle with co-learners. It should be easy monitor by teachers.

\section{Determine Physical or Psychological Problem}

The teacher ought to determine any physical or psychological drawback of students. Teacher should identify and categories the children who are suffer in eye defect, laziness, postural imbalance etc. for physically disabled and mal adjustment, disobey, immoral attitudes etc. for psychologically disabled. Then take suitable measurement for them with the help of parents and members of educational institutions.

\section{Generating Self-Confidence Level}

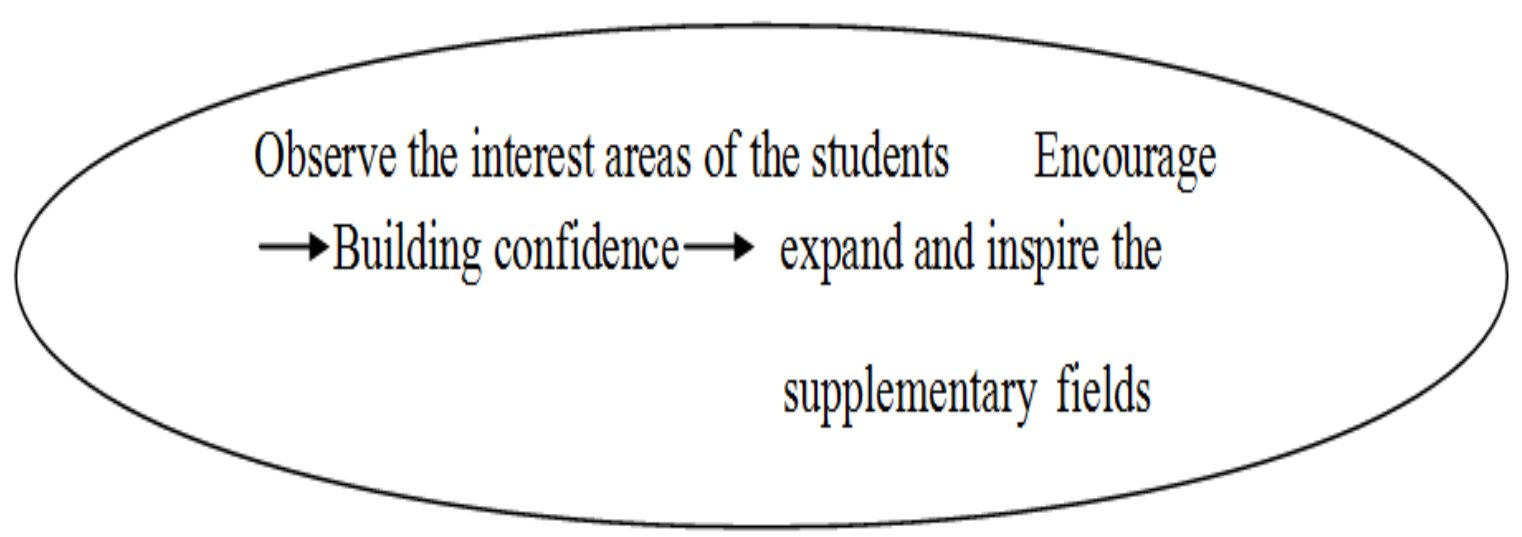

\section{To be a Associate}

Teacher should make close relationship with needed students and to be a friend to the weak students. The beginning affection makes the children to surrender to the teacher.

Inclusion is not with reference to together with learners with disabilities. It is concerning clutch the through that diversity is that the reality and therefore, each child is a unique learner. Learners learn and use their learning differently. Today's learners in faculties is also culturally or linguistically completely different or they will suffer from minor or major disabilities, they may come from different families or socio - economic background or they may be underprivileged because of economics, social, cultural, linguistic, gender, administrative, vocational disabilities or other factors.

Learning Disabilities will turn up in learners in varied ways that and hamper their ability to concentrate, think, speak, read, write, spell or to try to mathematical calculations this learners might suffer from some impairment in perception conceptualization, language, memory, attention or control.

It is hoped that faculties can understand this serious concern and take acceptable initiatives to deal with these problems. The board with in the meanwhile is additionally within the method of transportation out a document on comprehensive practices in class education inclusive thinking and practise involve learners with disabilities in through 
education curricular assessment practices and schoolrooms dealings that encourage the final and subject teacher to figure along for the benefit of each students.

\section{CONCLUSIONS}

By following these ways in our schools, children will develop self-confidence; improve their interaction with others in positive way; receive good academic and non-academic skills; be trained being together. So if we practice the CBSE's suggestions of concessions and advices on disability children in our schools, we can positively achieve the goals of inclusive education.

\section{REFERENCES}

1. K. Umamakeswari, Inclusive Education, Santa Publications

2. M. R. Uma Devi (2000), Special Education

3. M. Manivannan, Inclusive Education for Disabled Children

4. Garai, S. K., \& Chakraborty, A. Requirement of Internal quality Assurance for Higher Education.

5. Mangal S K (2000), Educating Exceptional Children: An Introduction to Special Education

6. Richard A Villa (2005), Creating an inclusive school

7. Johan, R., \& Harlan, J. (2014). Education nowadays. International Jounal of Educational Science and Research (IJESR), 4(5), 51-56.

8. Sadhana Parashar (29 $9^{\text {th }}$ Oct'2008), Inclusive Education, CBSE, Circular 45

9. http://community.fpg.unc.edu/ 